Article

\title{
Novel Entropy and Rotation Forest-Based Credal Decision Tree Classifier for Landslide Susceptibility Modeling
}

\author{
Qingfeng $\mathrm{He}^{1, *}$, Zhihao $\mathrm{Xu}^{1}{ }^{1}$, Shaojun $\mathrm{Li}^{2, *}$, Renwei $\mathrm{Li}^{1}{ }^{1}$, Shuai Zhang ${ }^{1}$, Nianqin Wang ${ }^{1}$, \\ Binh Thai Pham ${ }^{3, *}$ and Wei Chen ${ }^{1, *(1)}$ \\ 1 College of Geology \& Environment, Xi'an University of Science and Technology, Xi'an 710054, Shaanxi, \\ China; 17209212034@stu.xust.edu.cn (Z.X.); 17209074018@stu.xust.edu.cn (R.L.); \\ 16209062016@stu.xust.edu.cn (S.Z.); wangnianqin@xust.edu.cn (N.W.) \\ 2 State Key Laboratory of Geomechanics and Geotechnical Engineering, Institute of Rock and Soil Mechanics, \\ Chinese Academy of Sciences, Wuhan 430071, Hubei, China \\ 3 Institute of Research and Development, Duy Tan University, Da Nang 550000, Vietnam \\ * Correspondence: heqf@xust.edu.cn (Q.H.); sjli@whrsm.ac.cn (S.L.); phambinhgtvt@gmail.com (B.T.P.); \\ chenwei0930@xust.edu.cn (W.C.); Tel.: +86-029-8558-3114 (W.C.)
}

Received: 25 December 2018; Accepted: 22 January 2019; Published: 23 January 2019

\begin{abstract}
Landslides are a major geological hazard worldwide. Landslide susceptibility assessments are useful to mitigate human casualties, loss of property, and damage to natural resources, ecosystems, and infrastructures. This study aims to evaluate landslide susceptibility using a novel hybrid intelligence approach with the rotation forest-based credal decision tree (RF-CDT) classifier. First, 152 landslide locations and 15 landslide conditioning factors were collected from the study area. Then, these conditioning factors were assigned values using an entropy method and subsequently optimized using correlation attribute evaluation (CAE). Finally, the performance of the proposed hybrid model was validated using the receiver operating characteristic (ROC) curve and compared with two well-known ensemble models, bagging (bag-CDT) and MultiBoostAB (MB-CDT). Results show that the proposed RF-CDT model had better performance than the single CDT model and hybrid bag-CDT and MB-CDT models. The findings in the present study overall confirm that a combination of the meta model with a decision tree classifier could enhance the prediction power of the single landslide model. The resulting susceptibility maps could be effective for enforcement of land management regulations to reduce landslide hazards in the study area and other similar areas in the world.
\end{abstract}

Keywords: rotation forest; credal decision tree; ensemble model; machine learning; landslide

\section{Introduction}

Landslides, one of the most frequent geological hazards in China, cause thousands of millions of dollars in damage, dozens of casualties, and many geological environment problems every year [1-5]. In order to reduce the losses caused by landslides, predicting the areas where landslides are most likely to occur has become more important [3,6]. Landslide susceptibility research is an important approach to predicting the spatial distribution of landslides, which can be regarded as the spatial probability of landslide occurrence, according to a series of geoenvironmental conditions [7].

A landslide is a pattern of transforming the Earth's surface under the influence of human activities [8-10]. Landslide is complex movement under the action of multiple factors, such as altitude, slope angle, rainfall, lithology, land use, and so on [11-13]. In recent years, more researchers 
have coupled geographic information systems (GISs) and assessment methods to study landslide susceptibility mapping, which has been confirmed to be effective [14-16].

As there are no universal methods in landslide susceptibility mapping, various approaches have been used to study landslide susceptibility, such as statistical models of entropy [17-21], evidential belief function [22,23], frequency ratio [24-26], weight of evidence [19,27], certainty factors [28-30], logistic regression models [31-33], and generalized additive models [34,35].

In addition to the above traditional statistical methods, various machine learning techniques have been introduced for landslide susceptibility mapping, such as artificial neural networks [24,36-39], support vector machines [34,40-42], naïve Bayes trees [43-45], alternating decision trees [46-48], rotation forests $[32,49,50]$, kernel logistic regression [51,52], adaptive neuro-fuzzy inference systems [34,53,54], logistic model trees [49,52], and classification and regression trees [55-57]. However, the best method for landslide susceptibility mapping is still under discussion [58].

This paper takes Linyou County (China) as the study area and uses a novel, intelligent hybrid approach - a rotation-forest-based [59] credal decision tree classifier (RF-CDT) [60]-for landslide susceptibility mapping. In addition, two well-known ensemble models, bagging [61] and MultiBoostAB [62], were used as benchmark methods for comparison purposes. The results were validated by the area under the receiver operating characteristic (ROC) curve and statistical analysis. These landslide susceptibility maps were obtained in Linyou County and can be used for landslide mitigation and land use planning.

\section{Study Area}

Linyou County is located in the northeast of Baoji City in Shaanxi Province, China. It lies between longitudes of $107^{\circ} 19^{\prime}-108^{\circ} 2^{\prime} \mathrm{E}$ and latitudes of $34^{\circ} 33^{\prime}-34^{\circ} 58^{\prime} \mathrm{N}$ (Figure 1). Linyou County belongs to the temperate semihumid-humid monsoon climate zone. The climate is characterized by insufficient heat, droughty spring, cool summer, wet autumn, and cold winter. The average temperature is $9.1{ }^{\circ} \mathrm{C}$. The annual average rainfall is $680 \mathrm{~mm}$, mostly concentrated from July to September, accounting for more than $50 \%$ of the annual rainfall [63].

Topographically, the elevation increases from southeast to northwest, with average, highest, and lowest elevations of 1271, 1661, and $724 \mathrm{~m}$, respectively. Slope angles of Linyou County range from 0 to $64.67^{\circ}$. Most of the slope angles are in the range of $10-20^{\circ}(42.375 \%)$, followed by $20-30^{\circ}$ (27.160\%), $0-10^{\circ}(22.910 \%), 30-40^{\circ}(6.829 \%), 40-50^{\circ}(0.700 \%), 50-60^{\circ}(0.026 \%)$, and $>60^{\circ}(0.001 \%)$. Soil types are mainly Calcaric Cambisol (82.702\%) and Eutric Cambisol (12.653\%).

\section{Materials and Methods}

\subsection{Data Preparation}

A landslide inventory map contains the previous locations of landslides [64]. In the current study, interpretations of multitemporal Google Earth data and historical records of landslides were used to prepare the primary landslide inventory map; furthermore, field surveys by handheld Global Positioning System (GPS) devices were carried out to verify landslide locations. Finally, a total of 152 landslides were mapped (Figure 1) and digitalized using ArcGIS software (Esri, Redlands, CA, USA) [65], including 113 slides and 39 falls [66], and were randomly divided into two parts (70/30) for the building and validation of models.

The selection of conditioning factors is the foundation of landslide susceptibility assessment, and it has a direct impact on the evaluation results. However, there is no clear agreement with the precise cause of landslides due to their complex nature and development. Based on previous studies [67-69] and the geoenvironmental characteristics of the study area, 15 conditioning factors were selected: attitude, slope angle, slope aspect, plan curvature, profile curvature, sediment transport index (STI), stream power index (SPI), topographic wetness index (TWI), distance to rivers, distance to roads, normalized difference vegetation index (NDVI), soil, land use, lithology, and rainfall. 

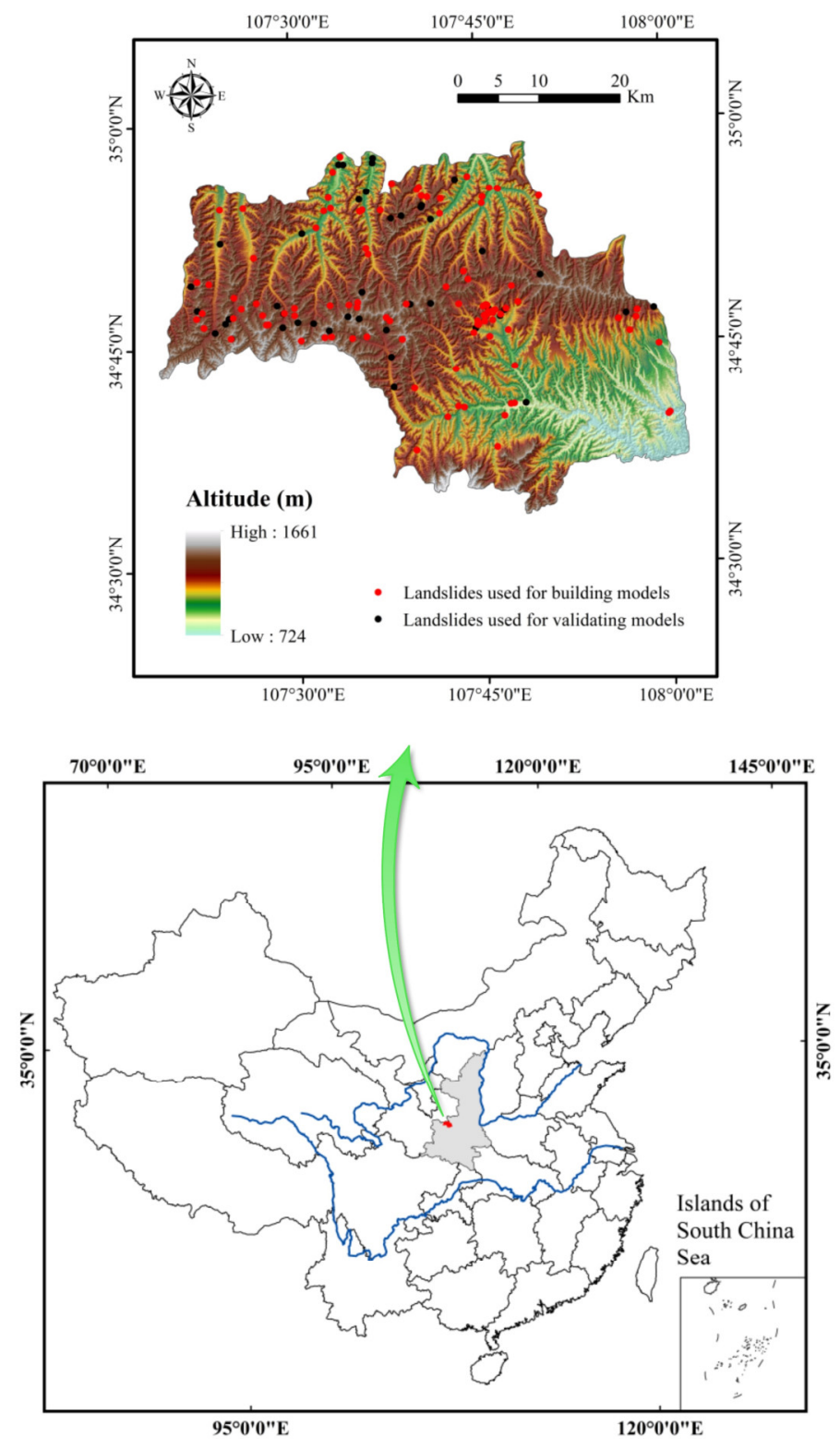

Figure 1. Study area.

Altitude, which greatly influences topographic attributes and controls differences in vegetation distribution, is one of the most commonly used factors in landslide susceptibility studies [70-72]. The altitude map (Figure 2a) was achieved from ASTER GDEM data with a resolution of $30 \mathrm{~m}$ collected from the National Aeronautics and Space Administration (NASA) [73]. In addition, DEM data were used to generate slope angle (Figure 2b), slope aspect (Figure 2c), plan curvature (Figure 2d), profile curvature (Figure 2e), STI (Figure 2f), SPI (Figure 2g), and TWI (Figure 2h) by GIS software [74,75]. 
Distances to rivers, which can influence the hydrologic processes of a slope, were obtained by buffering the river network from the topographic maps at the 1:50,000 scale (Figure 2i). Meanwhile, distances to roads were constructed by the same method from the road distribution maps (Figure 2j). This can be regarded as the impact of human activities on landslides, which causes a loss of toe support and changes the landform. NDVI is an index that shows the vegetation growth state and coverage. It can affect the stability of landslides through the reinforcement of plant roots and the permeability of surface soil (Figure 2k) [76-78].

The physical and mechanical properties of soil vary with soil type. They also influence the infiltration of surface water and the flow of ground water $[79,80]$. The soil types in the study area were classified into six classes (Figure 21). Land use, an important conditioning factor in landslide susceptibility assessment, has been employed in many studies [81,82], and was classified into six types for this study (Figure 2m). Lithology is also a frequently used factor in landslide susceptibility analysis, because different rock strata have different physical and mechanical properties $[67,83]$. The lithology map was achieved from the geological maps at a scale of 250,000 and reclassified into 13 classes (Table 1, Figure 2n). Rainfall, widely considered as a controlling factor in landslide occurrence, can reduce the strength of rock and soil mass and increase slope weight [84-86]. The data were obtained from the Shaanxi Provincial Meteorological Bureau [87], and the maximum and minimum annual rainfall were 650 and $329 \mathrm{~mm}$, respectively, in 2015 (Figure 2o).

Table 1. Lithology of the study area.

\begin{tabular}{|c|c|c|}
\hline Name & Lithology & Geological Age \\
\hline Group A & Loess & Quaternary \\
\hline Group B & Gravel, fine sandstone, argillaceous silt & Quaternary \\
\hline Group C & $\begin{array}{l}\text { Brown-red calcareous clay rock interbedded with sandy } \\
\text { clay rock, sandstone, and glutenite }\end{array}$ & Neogene \\
\hline Group D & $\begin{array}{l}\text { Sandstone interbedded with mudstone; mudstone and } \\
\text { siltstone interbedded with sandstone }\end{array}$ & Cretaceous \\
\hline Group E & $\begin{array}{l}\text { Powder-fine sandstone, mudstone interbedded with tuff } \\
\text { and marlstone }\end{array}$ & Cretaceous \\
\hline Group F & Sandstone interbedded with conglomerate & Cretaceous \\
\hline Group G & Conglomerate interbedded with glutenite and sandstone & Cretaceous \\
\hline Group H & $\begin{array}{l}\text { Feldspathic sandstone, mudstone, siltstone, coarse } \\
\text { sandstone, fine conglomerate }\end{array}$ & Jurassic \\
\hline Group I & $\begin{array}{c}\text { Interbedded sandstone and mudstone, coarse sandstone, } \\
\text { sandstone, coal seam }\end{array}$ & Jurassic \\
\hline Group J & $\begin{array}{l}\text { Interbedded sandstone and mudstone, marlstone, } \\
\text { conglomerate, sandstone, siltstone, shale, oil shale }\end{array}$ & Triassic \\
\hline Group K & $\begin{array}{l}\text { Sandstone interbedded with mudstone, siltstone, and } \\
\text { coal seam }\end{array}$ & Permian \\
\hline Group L & $\begin{array}{l}\text { Conglomerate, siliceous dolomite, shale, shale } \\
\text { interbedded with sandstone }\end{array}$ & Ordovician \\
\hline Group M & $\begin{array}{l}\text { Upper: argillaceous dolomite Middle: fine-grained } \\
\text { dolomite Bottom: spatulate dolomite, oolitic dolomite }\end{array}$ & Cambrian \\
\hline
\end{tabular}



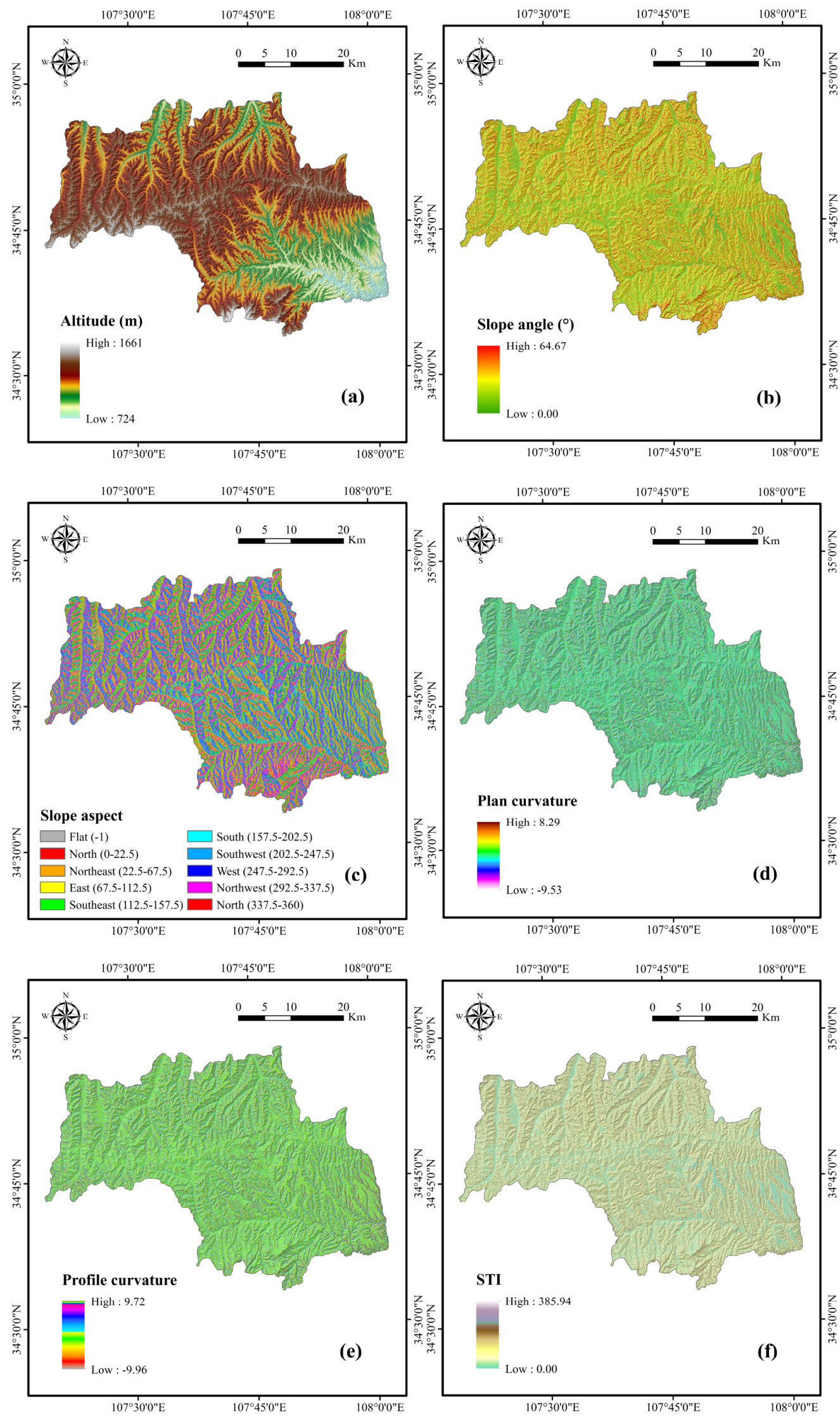

Figure 2. Cont. 

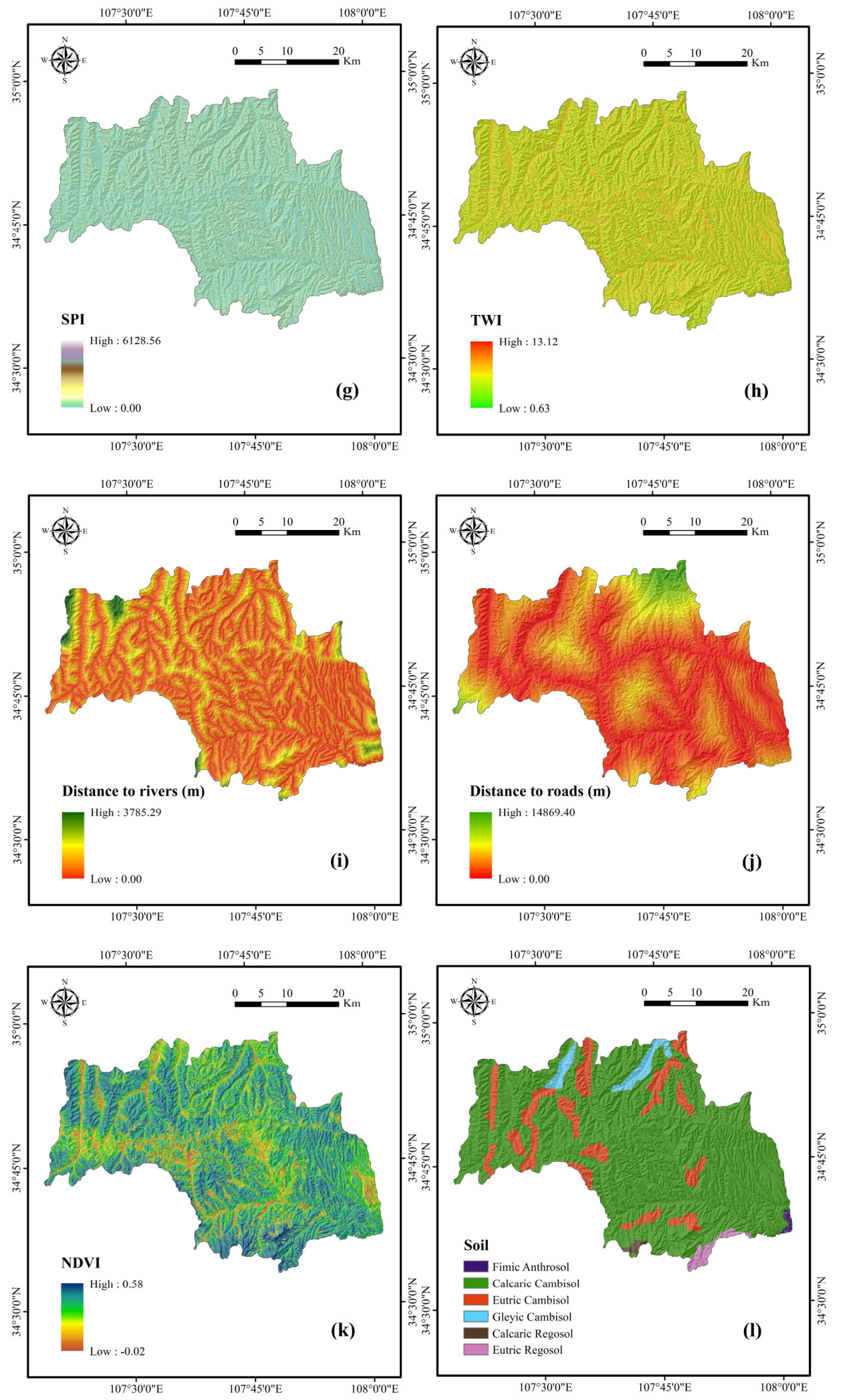

Figure 2. Cont. 

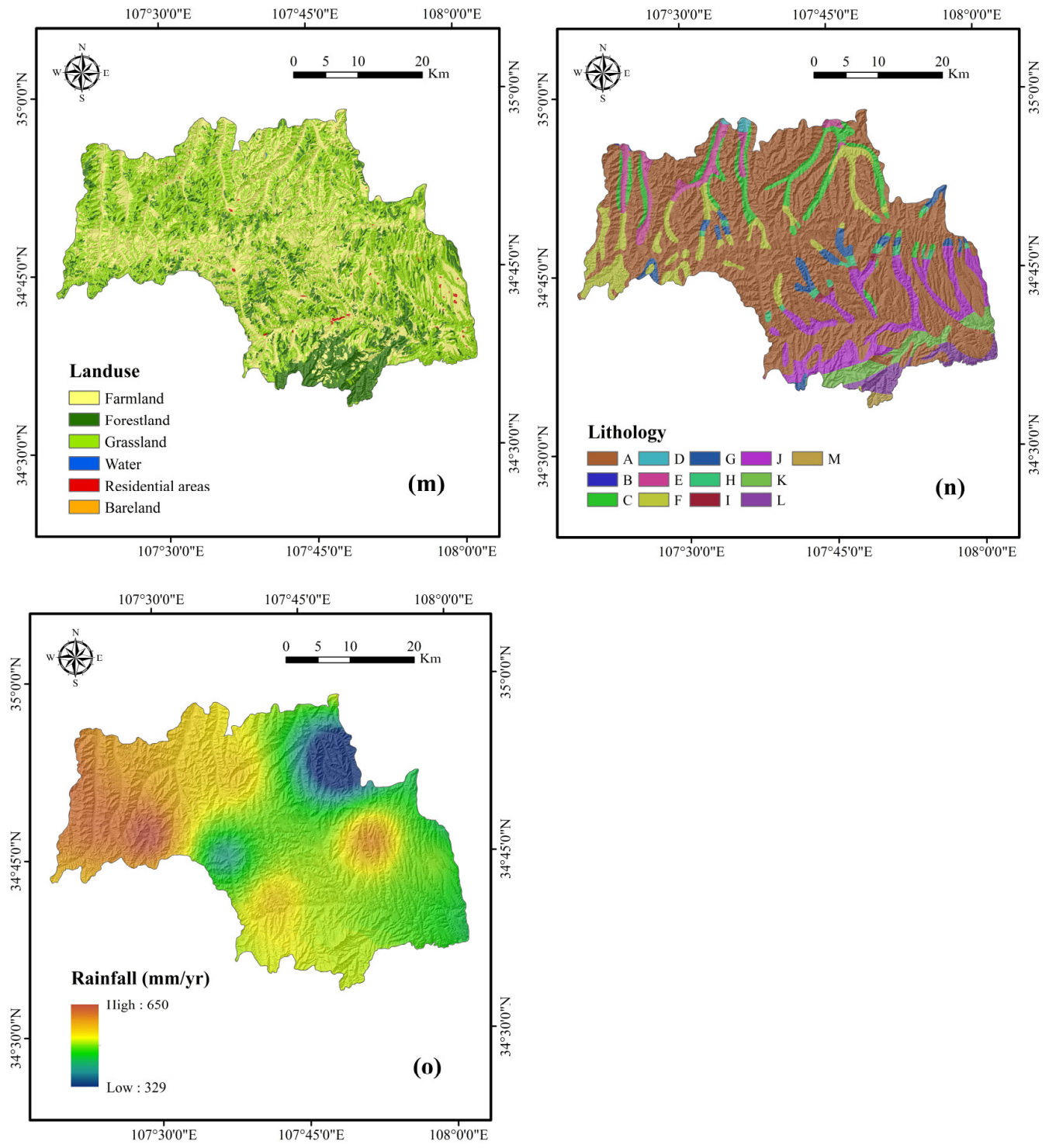

Figure 2. Thematic maps of the study area: (a) altitude; (b) slope angle; (c) slope aspect; (d) plan curvature; (e) profile curvature; (f) sediment transport index (STI); (g) stream power index (SPI); (h) topographic wetness index (TWI); (i) distance to rivers; (j) distance to roads; (k) normalized difference vegetation index (NDVI); (l) soil; (m) land use; (n) lithology; (o) rainfall.

\subsection{Index of Entropy (IoE)}

The entropy of a landslide refers to the extent to which various conditioning factors influence its development [20]. The equations used to calculate the information coefficient $W_{j}$ representing the weight values for the various conditioning factors $[17,18]$ are as follows:

$$
\begin{gathered}
P_{i j}=\frac{\text { Percentage of landslide }}{\text { Percentage of domain }} \\
\left(P_{i j}\right)=\frac{P_{i j}}{\sum_{j=1}^{S_{j}} P_{i j}}
\end{gathered}
$$

$H_{j \max }=\log _{2} S_{j}, S_{j}$ is the number of classes 


$$
\begin{gathered}
H_{j}=-\sum_{i=1}^{S j}\left(P_{i j}\right) \log _{2}\left(P_{i j}\right), j=1,2, \ldots, n \\
I_{j}=\frac{H_{j \max }-H_{j}}{H_{j \max }} \\
W_{j}=I_{j} \times P_{i j}
\end{gathered}
$$

where $H_{j}$ and $H_{j \max }$ are the entropy values, $I_{j}$ is the information coefficient, and $W_{j}$ is the resulting weight value for the factors as a whole [21].

\subsection{Credal Decision Tree}

The credal decision tree (CDT) was proposed by Abellán and Moral in 2003 to address classification problems with credal sets [60]. During the construction process of a CDT, to avoid generating a too-complicated decision tree, a novel criterion was introduced: stop when the total uncertainty increases due to branching of the decision tree [88]. Based on Dempster's and Shafer's theory [89,90], an improved method was created to quantitatively measure the total uncertainty of credal sets. The function used in total uncertainty measurement can be briefly expressed as Equation (7):

$$
\mathrm{TU}(\xi)=\mathrm{IG}(\xi)+\mathrm{GG}(\xi)
$$

where $\xi$ is a credal set on frame $X$, TU represents the value of total uncertainty, IG is a general function of nonspecificity on the corresponding credal set, and GG is a general function of randomness for a credal set. Abellán and Moral acquired sequences of conclusions and achievements related to total uncertainty measurement [91,92], and the calculation procedure of TU and properties of this measure are described systematically in relevant references.

The imprecise Dirichlet model [93] was employed to compute the probability intervals of a variable. Suppose that $Z$ is a variable whose values are represented by $z_{j}$, and the corresponding probability distribution $p\left(z_{j}\right)$ satisfies Equation (8) [94]:

$$
p\left(z_{j}\right) \in\left[\frac{n_{z_{j}}}{N+s}, \frac{n_{z_{j}}+s}{N+s}\right]
$$

where $n_{z_{j}}$ is the number of occurrences of the event where $Z=z_{j}, N$ is the sample size, and $S$ is a hyperparameter whose value is usually 1 or 2, according to Walley [93].

\subsection{Rotation Forest}

Generally, it is considered that classifier ensembles can improve the performance of a single classifier [59]. As a novel technique to construct classifier ensembles, the rotation forest (RF) model has been widely used in landslide susceptibility mapping with the aim of acquiring better prediction accuracy [95-97]. Suppose that $X$ is the original training data, and $X$ can be written as an $N \times n$ matrix ( $N$ is the number of training samples, and $n$ is the number of features). The corresponding class label set and feature set can be denoted as $Y$ and $F$, respectively. Assume that $L$ is the total number of decision tree classifiers in the RF algorithm, and the $i$ th decision tree is $D i(i=1,2, \ldots, L)$. In the RF algorithm, $F$ is first randomly split into $k$ subsets. We can then obtain $F_{i j}$ (the $j$ th feature subset for the $i$ th decision tree) and $X_{i j}$ (the training data for features in $F_{i j}$ ). Based on the bootstrap approach, a nonempty subset $X_{i j}^{\prime}$ is generated, whose size is $75 \%$ of the original training data. In the next step, an $M \times 1(M=n / k)$ coefficient vector is obtained by using linear transformation on $X_{i j^{\prime}}^{\prime}$, and the coefficient vector can 
be expressed as $\left\{a_{i j}^{1}, \ldots, a_{i j}^{M 1}\right\}$. Subsequently, a sparse rotation matrix $R_{i}$ can be created, shown as Equation (9):

$$
R_{i}=\left[\begin{array}{cccc}
a_{i 1}^{(1)}, \ldots, a_{i 1}^{(M 1)} & \{0\} & \ldots & \{0\} \\
\{0\} & a_{i 2}^{(2)}, \ldots, a_{i 2}^{(M 2)} & \ldots & \{0\} \\
\vdots & \vdots & \vdots & \vdots \\
\{0\} & \{0\} & \ldots & a_{i k}^{(k)}, \ldots, a_{i k}^{(M k)}
\end{array}\right] .
$$

In this way, the new training dataset for $D_{i}$ can be calculated as Equation (4), and all the single decision tree classifiers will be trained in a parallel manner [98].

$$
\text { Transformed training set }=X R_{i}^{a}
$$

where $R_{i}^{a}$ is the new sparse rotation matrix formed by rearranging the columns of $R_{i}$ according to the original feature set.

\subsection{Bagging}

Bagging is an abbreviation for "bootstrap aggregating", which is a technique to raise the accuracy of machine learning algorithms [61]. The main idea of bagging is that it generates an ensemble classifier composed of multiple base classifiers that are constructed with various bootstrapped training sets [99]. Bagging not only contributes to decreasing the classification variance but also can improve the generalization capability of the ensemble classifier [61]. It has been proved that the combining rule of base classifiers may have a notable effect on bagging performance [100]. Currently, the majority vote combining rule has been adopted extensively in bagging. The ultimate classification result can be obtained by the formula demonstrated in Equation (11):

$$
C^{*}(x)=\underset{y \in Y}{\operatorname{argmax}} \sum_{i=1}^{t} 1\left(C_{i}(x)=y\right)
$$

where $1\left(C_{i}(x)=y\right)$ is the indicator function.

\subsection{MultiBoostAB}

MultiBoostAB is the Waikato Environment for Knowledge Analysis (WEKA) version of MultiBoosting [62]. In essence, MultiBoosting is a combination of AdaBoost and wagging, a variant of bagging [101]. AdaBoost and bagging are two widely used techniques in the field of ensemble learning $[96,99,102]$. It was demonstrated that AdaBoost could remarkably decrease the bias and variance of classifiers, while bagging only had an attenuation effect on variance [103]. However, it has been proved that bagging has better performance in error reduction [61]. Compared with bagging, wagging determines random instance weights with the continuous Poisson distribution. Suppose that $i$ is the number of subcommittees, $I_{i}$ is a variable to limit the iterations of the $i$ th subcommittee, and $T$ represents the number of iterations. Values of $I_{i}$ can be calculated by Equation (12):

$$
\left\{\begin{array}{c}
n=\lfloor T\rfloor \\
I_{i}=\lceil i \times T / n\rceil(i=1,2, \cdots, n-1) \\
I_{i}=T(i=n, n+1, \cdots, \infty)
\end{array}\right.
$$

In the process of iteration, the weighted errors on training sets can be figured out by Equation (13). $\beta_{t}$ depends on the corresponding value of error, and the final classification function is shown as Equation (14) [101]:

$$
\varepsilon_{t}=\frac{\sum_{x_{j} \in S^{\prime}: C_{t}\left(x_{j}\right) \neq y_{j}} \operatorname{weight}\left(x_{j}\right)}{m}
$$




$$
C^{*}(x)=\underset{y \in Y}{\operatorname{argmax}} \sum_{t: C_{t}(x)=y} \log \frac{1}{\beta_{t}}
$$

where $\varepsilon_{t}$ refers to the weighted error, $m$ is the number of examples in the training sequence, and $C_{t}\left(x_{j}\right)$ is the classification result of the $t$ th base classifier.

\section{Results and Analysis}

\subsection{Selection of Landslide Conditioning Factors}

In the present study, the index of entropy model was used to reduce the unevenness among the factors and thereby provide a realistic status of their impact on landslide susceptibility (Table 2) [104]. The results of each class of the conditioning factors were then extracted as inputs to calculate the importance of conditioning factors and modeling landslide susceptibility. The result of the importance of conditioning factors by correlation attribute evaluation (CAE) [105] is shown in Table 3. It shows that all the conditioning factors contribute to the landslide susceptibility model. NDVI, with an average merit (AM) of 0.273 , has the highest $\mathrm{AM}$ of all the conditioning factors, followed by distance to roads $(\mathrm{AM}=0.242)$, land use $(\mathrm{AM}=0.191)$, distance to rivers $(\mathrm{AM}=0.127)$, rainfall $(\mathrm{AM}=0.092)$, STI $(\mathrm{AM}=0.091)$, SPI $(\mathrm{AM}=0.090)$, profile curvature $(\mathrm{AM}=0.072)$, plan curvature $(\mathrm{AM}=0.060)$, lithology $(A M=0.055)$, TWI $(A M=0.048)$, soil $(A M=0.044)$, slope aspect $(A M=0.025)$, slope angle $(A M=0.015)$, and altitude ( $\mathrm{AM}=0.014)$. All 15 conditioning factors were applied to create the landslide susceptibility maps in the study area in virtue of their positive contributions to the models.

Table 2. Correlation between landslides and conditioning factors using the index of entropy (IoE) method.

\begin{tabular}{ccccccc}
\hline $\begin{array}{c}\text { Conditioning } \\
\text { Factor }\end{array}$ & Classes & $\begin{array}{c}\text { Percentage } \\
\text { of Domain }\end{array}$ & $\begin{array}{c}\text { Percentage of } \\
\text { Landslides }\end{array}$ & $\left.\mathbf{( P}_{\mathbf{i j}}\right)$ & $\mathbf{I}_{\mathbf{j}}$ & $\mathbf{W}_{\mathbf{j}}$ \\
\hline Altitude $(\mathrm{m})$ & $724-800$ & 0.103 & 0.000 & 0.000 & 0.203 & 0.168 \\
\hline & $800-900$ & 0.779 & 1.887 & 0.292 & & \\
& $900-1000$ & 2.705 & 0.000 & 0.000 & & \\
& $1000-1100$ & 7.581 & 6.604 & 0.105 & & \\
& $1100-1200$ & 14.306 & 21.698 & 0.183 & & \\
& $1200-1300$ & 24.928 & 27.358 & 0.132 & & \\
& $1300-1400$ & 30.262 & 21.698 & 0.086 & & \\
& $1400-1500$ & 17.504 & 19.811 & 0.136 & & \\
& $1500-1600$ & 1.733 & 0.943 & 0.066 & & \\
& $1600-1661$ & 0.099 & 0.000 & 0.000 & & \\
& $0-10$ & 22.910 & 23.585 & 0.244 & 0.229 & 0.162 \\
& $10-20$ & 42.375 & 41.509 & 0.232 & & \\
& $20-30$ & 27.160 & 26.415 & 0.230 & & \\
& $30-40$ & 6.829 & 8.491 & 0.294 & & \\
& $40-50$ & 0.700 & 0.000 & 0.000 & & \\
& $50-64.67$ & 0.027 & 0.000 & 0.000 & & \\
\hline
\end{tabular}


Table 2. Cont.

\begin{tabular}{|c|c|c|c|c|c|c|}
\hline $\begin{array}{l}\text { Conditioning } \\
\text { Factor }\end{array}$ & Classes & $\begin{array}{l}\text { Percentage } \\
\text { of Domain }\end{array}$ & $\begin{array}{l}\text { Percentage of } \\
\text { Landslides }\end{array}$ & $\left(\mathbf{P}_{\mathrm{ij}}\right)$ & $\mathbf{I}_{\mathbf{j}}$ & $\mathbf{W}_{\mathbf{j}}$ \\
\hline \multirow[t]{9}{*}{ Slope aspect } & Flat & 0.028 & 0.000 & 0.000 & 0.095 & 0.085 \\
\hline & North & 11.352 & 6.604 & 0.072 & & \\
\hline & Northeast & 13.563 & 10.377 & 0.094 & & \\
\hline & East & 14.844 & 16.038 & 0.133 & & \\
\hline & Southeast & 11.877 & 22.642 & 0.235 & & \\
\hline & South & 10.414 & 14.151 & 0.168 & & \\
\hline & Southwest & 12.378 & 15.094 & 0.151 & & \\
\hline & West & 13.614 & 7.547 & 0.068 & & \\
\hline & Northwest & 11.928 & 7.547 & 0.078 & & \\
\hline \multirow[t]{3}{*}{ Plan curvature } & Concave & 45.118 & 34.906 & 0.240 & 0.020 & 0.021 \\
\hline & Plan & 8.877 & 11.321 & 0.396 & & \\
\hline & Convex & 46.005 & 53.774 & 0.363 & & \\
\hline \multirow[t]{3}{*}{ Profile curvature } & Concave & 45.281 & 48.113 & 0.361 & 0.002 & 0.002 \\
\hline & Plan & 7.095 & 6.604 & 0.316 & & \\
\hline & Convex & 47.624 & 45.283 & 0.323 & & \\
\hline \multirow{5}{*}{ STI } & $<10$ & 76.576 & 82.075 & 0.324 & 0.345 & 0.228 \\
\hline & $10-20$ & 17.018 & 12.264 & 0.218 & & \\
\hline & $20-30$ & 3.726 & 5.660 & 0.459 & & \\
\hline & $30-40$ & 1.317 & 0.000 & 0.000 & & \\
\hline & $>40$ & 1.363 & 0.000 & 0.000 & & \\
\hline \multirow[t]{5}{*}{ SPI } & $<10$ & 56.676 & 59.434 & 0.223 & 0.054 & 0.051 \\
\hline & 10-20 & 19.037 & 23.585 & 0.263 & & \\
\hline & $20-30$ & 7.932 & 2.830 & 0.076 & & \\
\hline & $30-40$ & 4.124 & 5.660 & 0.291 & & \\
\hline & $>40$ & 12.230 & 8.491 & 0.147 & & \\
\hline \multirow[t]{5}{*}{ TWI } & $<2$ & 56.140 & 62.264 & 0.332 & 0.160 & 0.107 \\
\hline & $2-3$ & 35.052 & 31.132 & 0.266 & & \\
\hline & $3-4$ & 6.804 & 5.660 & 0.249 & & \\
\hline & $4-5$ & 1.845 & 0.943 & 0.153 & & \\
\hline & $>5$ & 0.159 & 0.000 & 0.000 & & \\
\hline \multirow{5}{*}{$\begin{array}{l}\text { Distance to } \\
\text { rivers }(\mathrm{m})\end{array}$} & $<200$ & 26.385 & 28.302 & 0.219 & 0.018 & 0.017 \\
\hline & $200-400$ & 22.387 & 28.302 & 0.258 & & \\
\hline & $400-600$ & 17.492 & 19.811 & 0.231 & & \\
\hline & $600-800$ & 12.379 & 9.434 & 0.156 & & \\
\hline & $>800$ & 21.357 & 14.151 & 0.135 & & \\
\hline \multirow{5}{*}{$\begin{array}{l}\text { Distance to } \\
\text { roads }(\mathrm{m})\end{array}$} & $<500$ & 16.524 & 27.358 & 0.299 & 0.036 & 0.040 \\
\hline & 500-1000 & 14.614 & 20.755 & 0.257 & & \\
\hline & $1000-1500$ & 12.738 & 9.434 & 0.134 & & \\
\hline & $1500-2000$ & 10.994 & 11.321 & 0.186 & & \\
\hline & $>2000$ & 45.130 & 31.132 & 0.125 & & \\
\hline \multirow[t]{5}{*}{ NDVI } & $-0.02-0.23$ & 7.755 & 16.981 & 0.288 & 0.216 & 0.328 \\
\hline & $0.23-0.32$ & 10.093 & 28.302 & 0.369 & & \\
\hline & $0.32-0.38$ & 18.757 & 41.509 & 0.291 & & \\
\hline & $0.38-0.44$ & 34.724 & 11.321 & 0.043 & & \\
\hline & $0.44-0.58$ & 28.672 & 1.887 & 0.009 & & \\
\hline \multirow[t]{6}{*}{ Soil } & Fimic Anthrosol & 0.328 & 0.000 & 0.000 & 0.436 & 0.325 \\
\hline & $\begin{array}{l}\text { Calcaric } \\
\text { Cambisol }\end{array}$ & 82.702 & 79.245 & 0.214 & & \\
\hline & Eutric Cambisol & 12.653 & 14.151 & 0.250 & & \\
\hline & Gleyic Cambisol & 2.750 & 6.604 & 0.536 & & \\
\hline & Calcaric Regosol & 0.377 & 0.000 & 0.000 & & \\
\hline & Eutric Regosol & 1.190 & 0.000 & 0.000 & & \\
\hline
\end{tabular}


Table 2. Cont.

\begin{tabular}{|c|c|c|c|c|c|c|}
\hline $\begin{array}{c}\text { Conditioning } \\
\text { Factor }\end{array}$ & Classes & $\begin{array}{l}\text { Percentage } \\
\text { of Domain }\end{array}$ & $\begin{array}{l}\text { Percentage of } \\
\text { Landslides }\end{array}$ & $\left(\mathbf{P}_{\mathrm{ij}}\right)$ & $\mathbf{I}_{\mathbf{j}}$ & $\mathbf{W}_{\mathbf{j}}$ \\
\hline \multirow[t]{6}{*}{ Land use } & Farmland & 34.928 & 65.094 & 0.282 & 0.477 & 0.525 \\
\hline & Forestland & 16.617 & 0.943 & 0.009 & & \\
\hline & Grassland & 48.185 & 33.019 & 0.104 & & \\
\hline & Water & 0.008 & 0.000 & 0.000 & & \\
\hline & Residential areas & 0.236 & 0.943 & 0.605 & & \\
\hline & Bareland & 0.025 & 0.000 & 0.000 & & \\
\hline \multirow[t]{13}{*}{ Lithology } & A & 65.720 & 52.830 & 0.043 & 0.239 & 0.343 \\
\hline & B & 0.021 & 0.000 & 0.000 & & \\
\hline & $\mathrm{C}$ & 5.811 & 5.660 & 0.052 & & \\
\hline & $\mathrm{D}$ & 0.251 & 0.943 & 0.201 & & \\
\hline & $\mathrm{E}$ & 3.165 & 9.434 & 0.160 & & \\
\hline & $\mathrm{F}$ & 7.254 & 7.547 & 0.056 & & \\
\hline & G & 2.576 & 12.264 & 0.255 & & \\
\hline & $\mathrm{H}$ & 0.965 & 2.830 & 0.157 & & \\
\hline & I & 0.245 & 0.000 & 0.000 & & \\
\hline & $\mathrm{J}$ & 8.257 & 6.604 & 0.043 & & \\
\hline & $\mathrm{K}$ & 3.074 & 1.887 & 0.033 & & \\
\hline & $\mathrm{L}$ & 2.336 & 0.000 & 0.000 & & \\
\hline & M & 0.326 & 0.000 & 0.000 & & \\
\hline \multirow{4}{*}{$\begin{array}{l}\text { Rainfall } \\
(\mathrm{mm} / \mathrm{yr})\end{array}$} & $<400$ & 2.041 & 0.000 & 0.000 & 0.210 & 0.161 \\
\hline & $400-500$ & 7.117 & 6.604 & 0.303 & & \\
\hline & $500-600$ & 74.158 & 74.528 & 0.328 & & \\
\hline & $>600$ & 16.684 & 18.868 & 0.369 & & \\
\hline
\end{tabular}

Table 3. Importance of conditioning factors based on correlation attribute evaluation (CAE).

\begin{tabular}{ccc}
\hline Landslide Conditioning Factor & Average Merit (AM) & Standard Deviation (SD) \\
\hline NDVI & 0.273 & \pm 0.019 \\
Distance to roads & 0.242 & \pm 0.014 \\
Land use & 0.191 & \pm 0.020 \\
Distance to rivers & 0.127 & \pm 0.019 \\
Rainfall & 0.092 & \pm 0.017 \\
STI & 0.091 & \pm 0.026 \\
SPI & 0.090 & \pm 0.032 \\
Profile curvature & 0.072 & \pm 0.017 \\
Plan curvature & 0.060 & \pm 0.023 \\
Lithology & 0.055 & \pm 0.015 \\
TWI & 0.048 & \pm 0.021 \\
Soil & 0.044 & \pm 0.016 \\
Slope aspect & 0.025 & \pm 0.017 \\
Slope angle & 0.015 & \pm 0.015 \\
Altitude & 0.014 & \pm 0.010 \\
\hline
\end{tabular}

\subsection{Generation of Landslide Susceptibility Maps}

After the training and validation processes of landslide models, landslide susceptibility maps were obtained in the following two steps. First, the probability of landslide occurrence (PLO) for each pixel was generated using the probability distribution functions of the CDT and RF-CDT models. In the second step, PLOs were reclassified by mathematical methods, such as standard deviation, equal interval, natural break, geometric interval, and quantile. In this study, the quantile method was exploited to divide the PLOs into five categories: very low, low, moderate, high, and very high. The quantile method is a standard classification method in ArcGIS software that provides a more comprehensive analysis for both linear and nonlinear models in practical problems and makes a useful supplement for general regression models $[106,107]$. Therefore, the landslide susceptibility mappings 
(LSMs) in this research were classified by the quantile method. Figures 3 and 4 present the results of LSMs for the CDT and RF-CDT models, respectively.

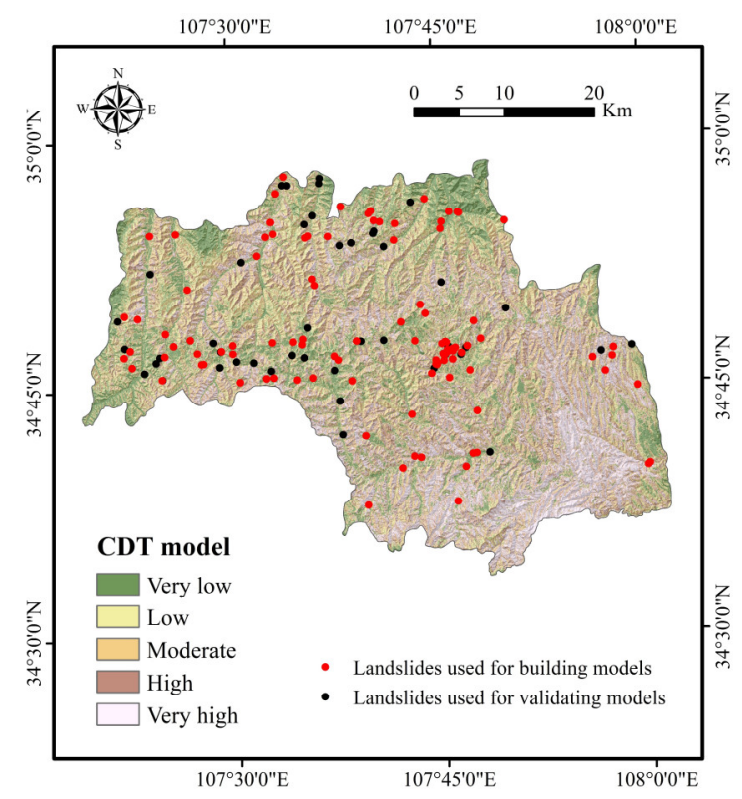

Figure 3. Landslide susceptibility map using the credal decision tree (CDT) model.

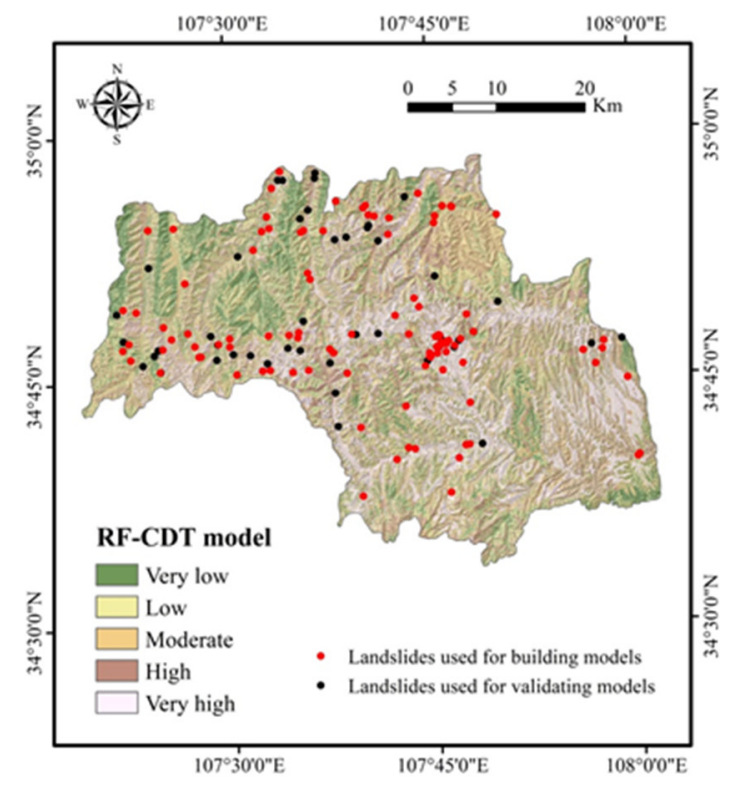

Figure 4. Landslide susceptibility map using the rotation forest (RF)-CDT model.

To further demonstrate the feasibility of the RF-CDT model in the landslide susceptibility study, two ensemble models, consisting of the CDT model as well as bagging and MultiBoostAB, were introduced to the benchmark models. The establishment, training, validation, and assessment processes of the benchmark models were the same as with the RF-CDT model, and landslide susceptibility maps generated by the benchmark models are shown in Figures 5 and 6 . Area percentages of landslide susceptibility classes of all models are shown in Figure 7. 


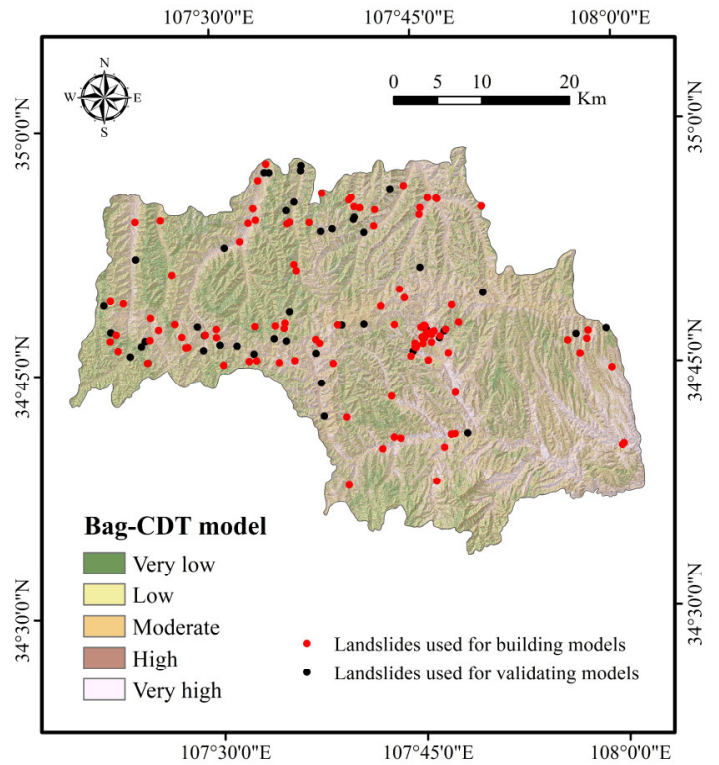

Figure 5. Landslide susceptibility map using the bag-CDT model.

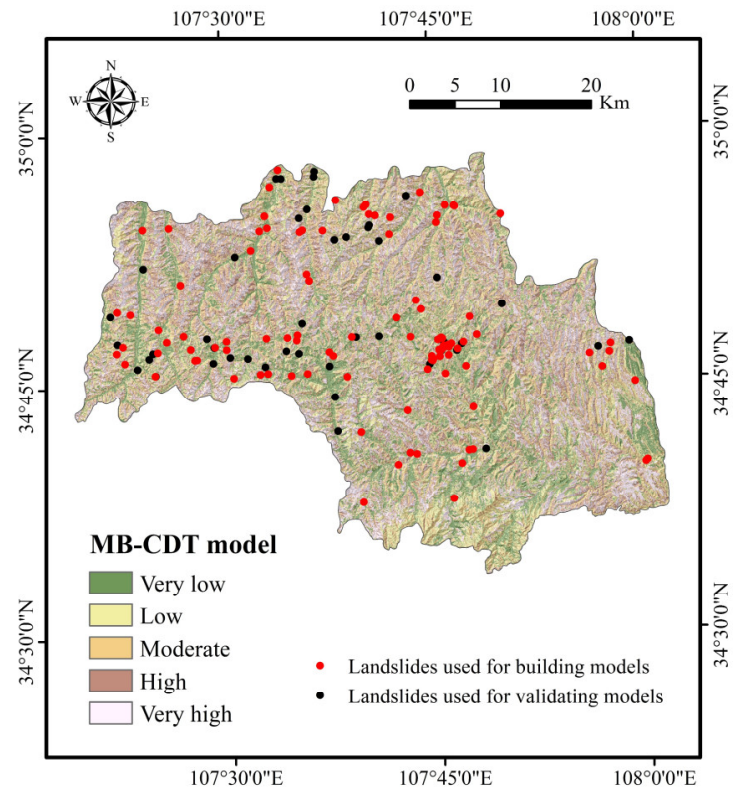

Figure 6. Landslide susceptibility map using the MultiBoostAB (MB)-CDT model. 


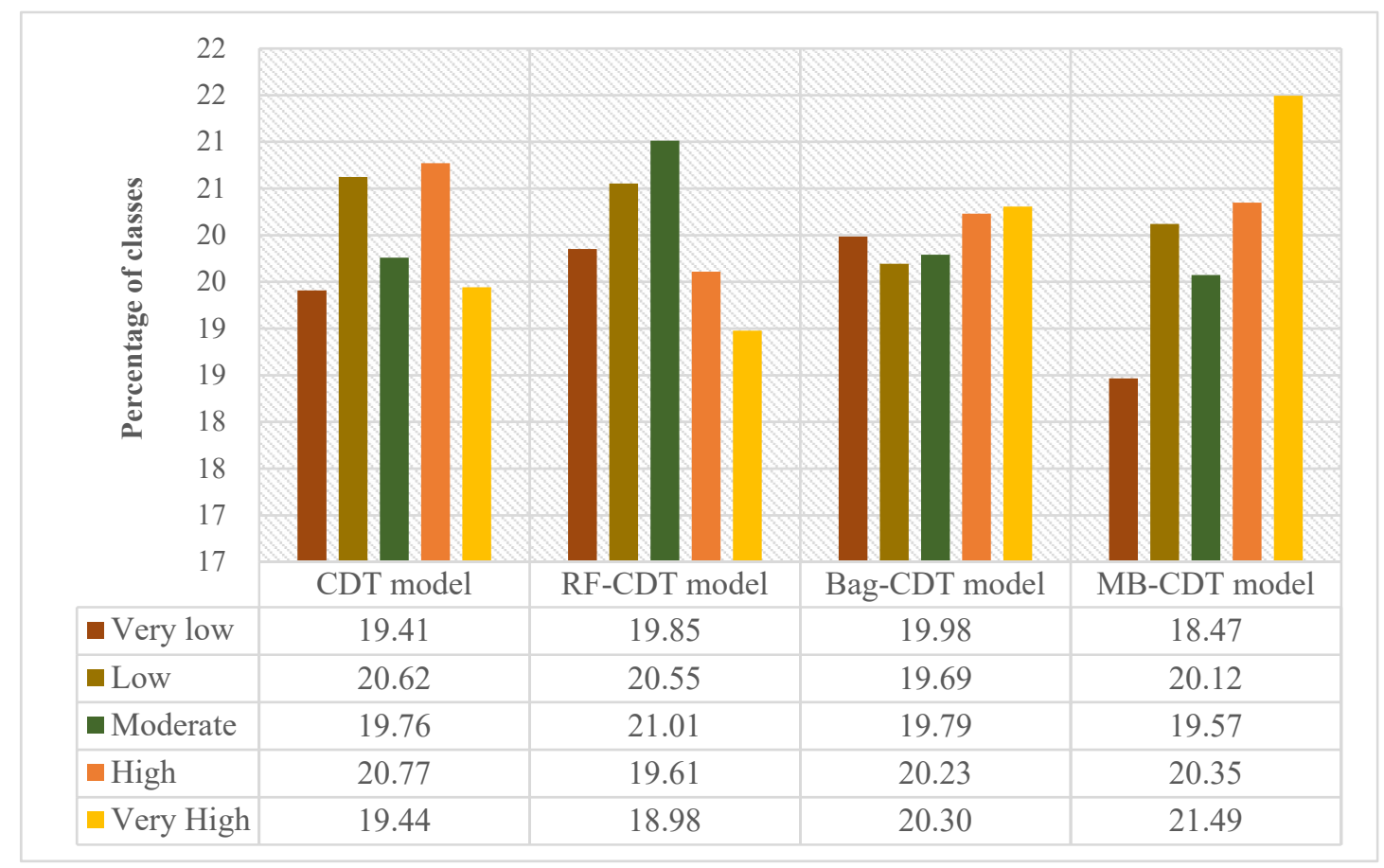

Figure 7. Area percentages of landslide susceptibility classes.

\subsection{Model Validation and Comparison}

In landslide susceptibility modeling, it is essential to validate and compare the quality of results. Validation of the results is regarded as one of the most important aspects of landslide susceptibility research, and the assessment results will not show scientific significance without validation $[34,108]$. In this paper, the prediction ability of the four models was evaluated using the receiver operating characteristic (ROC) curve $[109,110]$. The ROC curves and the parameters of the ROC curves using the training dataset are shown in Figure 7 and Table 4, respectively. Similarly, the ROC curves and the parameters of the ROC curves using the validation dataset are shown in Figures 8 and 9 and Table 5, respectively. In the training dataset, the RF-CDT model has the highest area under the ROC curve (AUC) value (0.813), followed by the bag-CDT model (0.809), the MB-CDT model (0.788), and the CDT model (0.779). The model with the highest AUC value for the validation dataset was RF-CDT (0.759), followed by bag-CDT (0.740), MB-CDT (0.729), and CDT (0.663). It can be concluded that the RF-CDT model had the best performance in both training and validation processes. All the evaluation results were obtained under a confidence interval (CI) at 95\%.

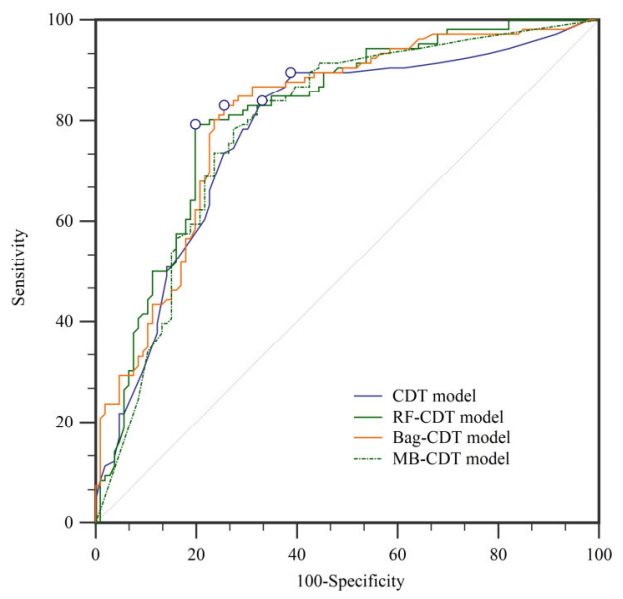

Figure 8. Receiver operating characteristic (ROC) curves using training dataset. 


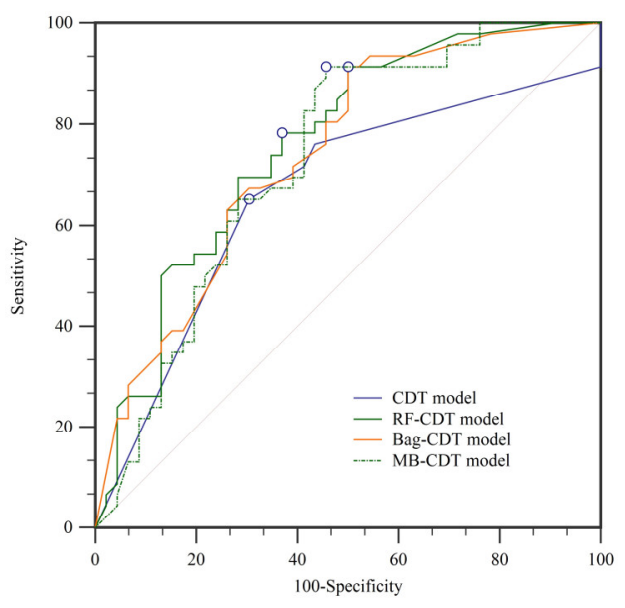

Figure 9. ROC curves using validation dataset.

Table 4. Parameters of ROC curves using training dataset. AUC: area under the receiver operating characteristic curve; SE: standard error; CI: confidence interval.

\begin{tabular}{cccc}
\hline Model & AUC & SE & $\mathbf{9 5 \% ~ C I ~}$ \\
\hline CDT & 0.779 & 0.0328 & 0.717 to 0.833 \\
RF-CDT & 0.813 & 0.0300 & 0.754 to 0.863 \\
Bag-CDT & 0.809 & 0.0302 & 0.750 to 0.860 \\
MB-CDT & 0.788 & 0.0320 & 0.727 to 0.841 \\
\hline
\end{tabular}

Table 5. Parameters of ROC curves using validation dataset.

\begin{tabular}{cccc}
\hline Model & AUC & SE & $\mathbf{9 5 \%}$ CI \\
\hline CDT & 0.663 & 0.0547 & 0.557 to 0.758 \\
RF-CDT & 0.759 & 0.0504 & 0.658 to 0.842 \\
Bag-CDT & 0.740 & 0.0515 & 0.638 to 0.826 \\
MB-CDT & 0.729 & 0.0537 & 0.626 to 0.816 \\
\hline
\end{tabular}

\section{Discussion}

Landslides have caused much financial loss and have threatened the safety of humans all over the world [111]. Various approaches have been used to study landslide susceptibility, and the research methods have evolved from simple statistical models to machine learning models. In order to achieve precise evaluation results, the use of new models in landslide susceptibility research has become more important. In this study, we chose the credal decision tree (CDT) as the basic model and combined it with rotation forest (RF), bagging (bag), and MultiBoostAB (MB) models to build ensemble models.

As there are no standards for selecting landslide conditioning factors [112], how to determine the conditioning factors has become a very important issue. In order to deal with it reasonably, the selection of conditioning factors in this paper was based on the geoenvironmental characteristics of the study area, the mechanism of landslide occurrence, and similar landslide susceptibility studies.

According to the importance analysis by the CAE model, it can be concluded that the NDVI, a commonly used conditioning factor that indicates the state of plant growth in the study area, is the most important landslide conditioning factor. According to its definition, the interval of NDVI value is $[-1,1]$ and the higher the value, the better the vegetation growth. The study area lies in hilly and valley regions of the Weibei dry plateau, one of the key areas of soil and water loss of Shaanxi Province, and rainfall is mainly concentrated from July to September. Therefore, under the joint action of uneven distribution of rainfall and serious soil erosion, the vegetation growth of the study area is relatively low, and the NDVI interval is $[-0.09,0.39]$. In addition, many studies have indicated that plants play a 
positive role in landslide occurrence because their root systems can increase soil strength and reduce water infiltration [113-115].

In the case of land use, the average merit is 0.191. It is well known that land use has a close relationship with human activities and may affect soil and water loss, precipitation infiltration, and surface structure [116]. It can be seen in Figure $2 \mathrm{~m}$ that farmland is the main type of land use. As the study area is located in the Weibei dry plateau, the infiltration of agricultural water will increase slope mass and reduce soil strength, which makes landslides occur more easily. It can be seen in Figures 4-7 that most landslides occur in low-altitude areas with nearby linear conditioning factors, such as distance to roads and rivers. Correspondingly, we can find that landslides decrease as we move away from roads and rivers. These results can also be found in similar studies $[117,118]$.

According to the parameters of ROC curves of the training and validation datasets, the RF-CDT model reflected the spatial distribution of landslides perfectly, while the CDT model had the lowest accuracy rate. The rotation forest model is a powerful new machine learning method that has been widely used in many fields and performed admirably in previous landslide susceptibility studies $[32,49,119]$. The bag-CDT model performed worse than the RF-CDT model, and its AUC values of training and validation datasets were 0.809 and 0.740 , respectively. The MB-CDT model ranked third, with training and validation dataset AUC values of 0.788 and 0.729 , respectively.

In a nutshell, the ensemble models in this paper expressed more promising results compared to single evaluation models in current studies $[96,120,121]$. Based on the CDT model combined with the $\mathrm{RF}$, bag, and MB models, landslide susceptibility in Linyou County was studied. As mentioned above, the RF-CDT model performed best in this research compared to other models. This raised a question as to why AUC values increased rapidly with the CDT model combined with the RF model. Perhaps the answer to this question can be explained as "slightly underperformed," which means that there should be a threshold for positive synergy among models [122,123]. In this paper, the RF model had the best cooperation with the CDT model. However, limits in different models have different interconnection rules that may be difficult to determine, especially when facing a series of factors with various ranges.

\section{Conclusions}

The present study allowed us to reach the following conclusions:

(1) The importance of conditioning factors was quantitatively defined by CAE. All 15 conditioning factors were applied to create the landslide susceptibility maps, and NDVI had the highest importance of all the conditioning factors.

(2) The proposed hybrid RF-CDT model, with AUC values of 0.813 and 0.759 , achieved good results in the training and validation phases compared to the single CDT model.

(3) The performance of the proposed hybrid RF-CDT model was also compared with the hybrid bag-CDT and MB-CDT models, and the results of AUC, SE, and CI at 95\% also indicate that the RF-CDT model is a promising method.

As a final remark, it is worth noting that the present study indicates that machine learning ensemble frameworks are promising techniques, and the obtained susceptibility maps may be employed to manage land use planning and landslide risk mitigation.

Author Contributions: Q.H., Z.X., R.L., S.Z. and W.C. collected field data and conducted the landslide mapping and analysis. Q.H., Z.X., R.L., S.Z. and W.C. wrote the manuscript. S.L., N.W. and B.P. provided critical comments in planning this paper and edited the manuscript. All the authors discussed the results and edited the manuscript.

Funding: This study was supported by a project funded by the International Partnership Program of the Chinese Academy of Sciences (grant no. 115242KYSB20170022), the National Natural Science Foundation of China (grant nos. 41807192, 41572287), the China Postdoctoral Science Foundation (grant nos. 2018T111084, 2017M613168), and a project funded by the Shaanxi Province Postdoctoral Science Foundation (grant no. 2017BSHYDZZ07).

Conflicts of Interest: No potential conflict of interest is reported by the authors. 


\section{References}

1. Ambrosi, C.; Strozzi, T.; Scapozza, C.; Wegmüller, U. Landslide hazard assessment in the himalayas (nepal and bhutan) based on earth-observation data. Eng. Geol. 2018, 237, 217-228. [CrossRef]

2. Palmisano, F.; Vitone, C.; Cotecchia, F. Methodology for landslide damage assessment. Procedia Eng. 2016, 161, 511-515. [CrossRef]

3. Pourghasemi, H.R.; Rahmati, O. Prediction of the landslide susceptibility: Which algorithm, which precision? CATENA 2018, 162, 177-192. [CrossRef]

4. Samodra, G.; Chen, G.; Sartohadi, J.; Kasama, K. Generating landslide inventory by participatory mapping: An example in purwosari area, yogyakarta, java. Geomorphology 2018, 306, 306-313. [CrossRef]

5. Zhuang, J.; Peng, J.; Wang, G.; Javed, I.; Wang, Y.; Li, W. Distribution and characteristics of landslide in loess plateau: A case study in shaanxi province. Eng. Geol. 2018, 236, 89-96. [CrossRef]

6. Chen, W.; Shahabi, H.; Zhang, S.; Khosravi, K.; Shirzadi, A.; Chapi, K.; Pham, B.T.; Zhang, T.; Zhang, L.; Chai, H.; et al. Landslide susceptibility modeling based on gis and novel bagging-based kernel logistic regression. Appl. Sci. 2018, 8, 2540. [CrossRef]

7. Chen, W.; Panahi, M.; Tsangaratos, P.; Shahabi, H.; Ilia, I.; Panahi, S.; Li, S.; Jaafari, A.; Ahmad, B.B. Applying population-based evolutionary algorithms and a neuro-fuzzy system for modeling landslide susceptibility. CATENA 2019, 172, 212-231. [CrossRef]

8. Chen, F.; Yu, B.; Xu, C.; Li, B. Landslide detection using probability regression, a case study of wenchuan, northwest of chengdu. Appl. Geogr. 2017, 89, 32-40. [CrossRef]

9. Ko, F.W.Y.; Lo, F.L.C. Rainfall-based landslide susceptibility analysis for natural terrain in hong kong-A direct stock-taking approach. Eng. Geol. 2016, 215, 95-107. [CrossRef]

10. Raška, P.; Zábranský, V.; Brázdil, R.; Lamková, J. The late little ice age landslide calamity in north bohemia: Triggers, impacts and post-landslide development reconstructed from documentary data (case study of the kozí vrch hill landslide). Geomorphology 2016, 255, 95-107. [CrossRef]

11. Chen, W.; Xie, X.; Peng, J.; Shahabi, H.; Hong, H.; Bui, D.T.; Duan, Z.; Li, S.; Zhu, A.X. Gis-based landslide susceptibility evaluation using a novel hybrid integration approach of bivariate statistical based random forest method. CATENA 2018, 164, 135-149. [CrossRef]

12. Martino, S.; Lenti, L.; Bourdeau, C. Composite mechanism of the büyükçekmece (turkey) landslide as conditioning factor for earthquake-induced mobility. Geomorphology 2018, 308, 64-77. [CrossRef]

13. Schmaltz, E.M.; Steger, S.; Glade, T. The influence of forest cover on landslide occurrence explored with spatio-temporal information. Geomorphology 2017, 290, 250-264. [CrossRef]

14. Chen, W.; Peng, J.; Hong, H.; Shahabi, H.; Pradhan, B.; Liu, J.; Zhu, A.X.; Pei, X.; Duan, Z. Landslide susceptibility modelling using gis-based machine learning techniques for chongren county, jiangxi province, china. Sci. Total Environ. 2018, 626, 1121-1135. [CrossRef]

15. Nicu, I.C. Frequency ratio and gis-based evaluation of landslide susceptibility applied to cultural heritage assessment. J. Cult. Herit. 2017, 28, 172-176. [CrossRef]

16. Chen, W.; Shahabi, H.; Shirzadi, A.; Li, T.; Guo, C.; Hong, H.; Li, W.; Pan, D.; Hui, J.; Ma, M.; et al. A novel ensemble approach of bivariate statistical-based logistic model tree classifier for landslide susceptibility assessment. Geocarto Int. 2018, 33, 1398-1420. [CrossRef]

17. Tien Bui, D.; Shahabi, H.; Shirzadi, A.; Chapi, K.; Alizadeh, M.; Chen, W.; Mohammadi, A.; Ahmad, B.; Panahi, M.; Hong, H.; et al. Landslide detection and susceptibility mapping by airsar data using support vector machine and index of entropy models in cameron highlands, malaysia. Remote Sens. 2018, 10, 1527. [CrossRef]

18. Chen, W.; Pourghasemi, H.R.; Naghibi, S.A. A comparative study of landslide susceptibility maps produced using support vector machine with different kernel functions and entropy data mining models in china. Bull. Eng. Geol. Environ. 2018, 77, 647-664. [CrossRef]

19. Tsangaratos, P.; Ilia, I.; Hong, H.; Chen, W.; Xu, C. Applying information theory and gis-based quantitative methods to produce landslide susceptibility maps in nancheng county, china. Landslides 2017, 14, 1091-1111. [CrossRef]

20. Youssef, A.M.; Al-Kathery, M.; Pradhan, B. Landslide susceptibility mapping at al-hasher area, jizan (saudi arabia) using gis-based frequency ratio and index of entropy models. Geosci. J. 2015, 19, 113-134. [CrossRef] 
21. Devkota, K.C.; Regmi, A.D.; Pourghasemi, H.R.; Yoshida, K.; Pradhan, B.; Ryu, I.C.; Dhital, M.R.; Althuwaynee, O.F. Landslide susceptibility mapping using certainty factor, index of entropy and logistic regression models in gis and their comparison at mugling-narayanghat road section in nepal himalaya. Nat. Hazards 2013, 65, 135-165. [CrossRef]

22. Regmi, A.D.; Poudel, K. Assessment of landslide susceptibility using gis-based evidential belief function in patu khola watershed, dang, nepal. Environ. Earth Sci. 2016, 75, 1-20. [CrossRef]

23. Tien Bui, D.; Pradhan, B.; Revhaug, I.; Nguyen, D.B.; Pham, H.V.; Bui, Q.N. A novel hybrid evidential belief function-based fuzzy logic model in spatial prediction of rainfall-induced shallow landslides in the lang son city area (vietnam). Geomat. Nat. Hazards Risk 2015, 6, 243-271.

24. Aditian, A.; Kubota, T.; Shinohara, Y. Comparison of gis-based landslide susceptibility models using frequency ratio, logistic regression, and artificial neural network in a tertiary region of ambon, indonesia. Geomorphology 2018, 318, 101-111. [CrossRef]

25. Ding, Q.; Chen, W.; Hong, H. Application of frequency ratio, weights of evidence and evidential belief function models in landslide susceptibility mapping. Geocarto Int. 2017, 32, 619-639. [CrossRef]

26. Zhang, Z.; Yang, F.; Chen, H.; Wu, Y.; Li, T.; Li, W.; Wang, Q.; Liu, P. Gis-based landslide susceptibility analysis using frequency ratio and evidential belief function models. Environ. Earth Sci. 2016, 75, 1-12. [CrossRef]

27. Razavizadeh, S.; Solaimani, K.; Massironi, M.; Kavian, A. Mapping landslide susceptibility with frequency ratio, statistical index, and weights of evidence models: A case study in northern iran. Environ. Earth Sci. 2017, 76, 499. [CrossRef]

28. Prefac, Z.; Dumitru, S.; Chendeș, V.; Sîrodoev, I.; Cracu, G. Assessment of landslide susceptibility using the certainty factor model: Răşcuţa catchment (curvature subcarpathians) case study. Carpath. J. Earth Environ. Sci. 2016, 11, 617-626.

29. Razandi, Y.; Pourghasemi, H.R.; Neisani, N.S.; Rahmati, O. Application of analytical hierarchy process, frequency ratio, and certainty factor models for groundwater potential mapping using gis. Earth Sci. Inf. 2015, 8, 867-883. [CrossRef]

30. Pourghasemi, H.R.; Pradhan, B.; Gokceoglu, C.; Mohammadi, M.; Moradi, H.R. Application of weights-of-evidence and certainty factor models and their comparison in landslide susceptibility mapping at haraz watershed, iran. Arab. J. Geosci. 2013, 6, 2351-2365. [CrossRef]

31. Colkesen, I.; Sahin, E.K.; Kavzoglu, T. Susceptibility mapping of shallow landslides using kernel-based gaussian process, support vector machines and logistic regression. J. Afr. Earth Sci. 2016, 118, 53-64. [CrossRef]

32. Trigila, A.; Iadanza, C.; Esposito, C.; Scarascia-Mugnozza, G. Comparison of logistic regression and random forests techniques for shallow landslide susceptibility assessment in giampilieri (ne sicily, italy). Geomorphology 2015, 249, 119-136. [CrossRef]

33. Tsangaratos, P.; Ilia, I. Comparison of a logistic regression and naïve bayes classifier in landslide susceptibility assessments: The influence of models complexity and training dataset size. CATENA 2016, 145, 164-179. [CrossRef]

34. Chen, W.; Pourghasemi, H.R.; Panahi, M.; Kornejady, A.; Wang, J.; Xie, X.; Cao, S. Spatial prediction of landslide susceptibility using an adaptive neuro-fuzzy inference system combined with frequency ratio, generalized additive model, and support vector machine techniques. Geomorphology 2017, 297, 69-85. [CrossRef]

35. Goetz, J.N.; Guthrie, R.H.; Brenning, A. Integrating physical and empirical landslide susceptibility models using generalized additive models. Geomorphology 2011, 129, 376-386. [CrossRef]

36. Chang, S.K.; Lee, D.H.; Wu, J.H.; Juang, C.H. Rainfall-based criteria for assessing slump rate of mountainous highway slopes: A case study of slopes along highway 18 in alishan, taiwan. Eng. Geol. 2011, 118, 63-74. [CrossRef]

37. Lin, H.-M.; Chang, S.-K.; Wu, J.-H.; Juang, C.H. Neural network-based model for assessing failure potential of highway slopes in the alishan, taiwan area: Pre- and post-earthquake investigation. Eng. Geol. 2009, 104, 280-289. [CrossRef]

38. Choi, J.; Oh, H.-J.; Lee, H.-J.; Lee, C.; Lee, S. Combining landslide susceptibility maps obtained from frequency ratio, logistic regression, and artificial neural network models using aster images and gis. Eng. Geol. 2012, 124, 12-23. [CrossRef] 
39. Conforti, M.; Pascale, S.; Robustelli, G.; Sdao, F. Evaluation of prediction capability of the artificial neural networks for mapping landslide susceptibility in the turbolo river catchment (northern calabria, italy). Catena 2014, 113, 236-250. [CrossRef]

40. Lin, G.-F.; Chang, M.-J.; Huang, Y.-C.; Ho, J.-Y. Assessment of susceptibility to rainfall-induced landslides using improved self-organizing linear output map, support vector machine, and logistic regression. Eng. Geol. 2017, 224, 62-74. [CrossRef]

41. Pham, B.T.; Jaafari, A.; Prakash, I.; Bui, D.T. A novel hybrid intelligent model of support vector machines and the multiboost ensemble for landslide susceptibility modeling. Bull. Eng. Geol. Environ. 2018, 1-22. [CrossRef]

42. Ada, M.; San, B.T. Comparison of machine-learning techniques for landslide susceptibility mapping using two-level random sampling (2lrs) in alakir catchment area, antalya, turkey. Nat. Hazards 2018, 90, 237-263. [CrossRef]

43. Pham, B.T.; Prakash, I. A novel hybrid model of bagging-based naïve bayes trees for landslide susceptibility assessment. Bull. Eng. Geol. Environ. 2017, 1-15. [CrossRef]

44. Chen, W.; Xie, X.; Peng, J.; Wang, J.; Duan, Z.; Hong, H. Gis-based landslide susceptibility modelling: A comparative assessment of kernel logistic regression, naïve-bayes tree, and alternating decision tree models. Geomat. Nat. Hazards Risk 2017, 8, 950-973. [CrossRef]

45. Chen, W.; Shirzadi, A.; Shahabi, H.; Ahmad, B.B.; Zhang, S.; Hong, H.; Zhang, N. A novel hybrid artificial intelligence approach based on the rotation forest ensemble and naïve bayes tree classifiers for a landslide susceptibility assessment in langao county, china. Geomat. Nat. Hazards Risk 2017, 8, 1955-1977. [CrossRef]

46. Pham, B.T.; Tien Bui, D.; Prakash, I. Landslide susceptibility assessment using bagging ensemble based alternating decision trees, logistic regression and j48 decision trees methods: A comparative study. Geotech. Geol. Eng. 2017, 35, 2597-2611. [CrossRef]

47. Pham, B.T.; Tien Bui, D.; Dholakia, M.; Prakash, I.; Pham, H.V. A comparative study of least square support vector machines and multiclass alternating decision trees for spatial prediction of rainfall-induced landslides in a tropical cyclones area. Geotech. Geol. Eng. 2016, 34, 1807-1824. [CrossRef]

48. Hong, H.; Pradhan, B.; Xu, C.; Tien Bui, D. Spatial prediction of landslide hazard at the yihuang area (china) using two-class kernel logistic regression, alternating decision tree and support vector machines. Catena 2015, 133, 266-281. [CrossRef]

49. Chen, W.; Xie, X.; Wang, J.; Pradhan, B.; Hong, H.; Tien Bui, D.; Duan, Z.; Ma, J. A comparative study of logistic model tree, random forest, and classification and regression tree models for spatial prediction of landslide susceptibility. CATENA 2017, 151, 147-160. [CrossRef]

50. Chen, W.; Pourghasemi, H.R.; Naghibi, S.A. Prioritization of landslide conditioning factors and its spatial modeling in shangnan county, china using gis-based data mining algorithms. Bull. Eng. Geol. Environ. 2018, 77, 611-629. [CrossRef]

51. Chen, W.; Shahabi, H.; Shirzadi, A.; Hong, H.; Akgun, A.; Tian, Y.; Liu, J.; Zhu, A.-X.; Li, S. Novel hybrid artificial intelligence approach of bivariate statistical-methods-based kernel logistic regression classifier for landslide susceptibility modeling. Bull. Eng. Geol. Environ. 2018, 1-23. [CrossRef]

52. Tien Bui, D.; Tuan, T.A.; Klempe, H.; Pradhan, B.; Revhaug, I. Spatial prediction models for shallow landslide hazards: A comparative assessment of the efficacy of support vector machines, artificial neural networks, kernel logistic regression, and logistic model tree. Landslides 2016, 13, 361-378. [CrossRef]

53. Nasiri Aghdam, I.; Varzandeh, M.H.M.; Pradhan, B. Landslide susceptibility mapping using an ensemble statistical index (wi) and adaptive neuro-fuzzy inference system (anfis) model at alborz mountains (iran). Environ. Earth Sci. 2016, 75, 1-20.

54. Tien Bui, D.; Pradhan, B.; Lofman, O.; Revhaug, I.; Dick, O.B. Landslide susceptibility mapping at hoa binh province (vietnam) using an adaptive neuro-fuzzy inference system and gis. Comput. Geosci. 2012, 45, 199-211. [CrossRef]

55. Pham, B.T.; Prakash, I.; Bui, D.T. Spatial prediction of landslides using a hybrid machine learning approach based on random subspace and classification and regression trees. Geomorphology 2018, 303, 256-270. [CrossRef] 
56. Youssef, A.M.; Pourghasemi, H.R.; Pourtaghi, Z.S.; Al-Katheeri, M.M. Landslide susceptibility mapping using random forest, boosted regression tree, classification and regression tree, and general linear models and comparison of their performance at wadi tayyah basin, asir region, saudi arabia. Landslides 2016, 13, 839-856. [CrossRef]

57. Felicísimo, Á.M.; Cuartero, A.; Remondo, J.; Quirós, E. Mapping landslide susceptibility with logistic regression, multiple adaptive regression splines, classification and regression trees, and maximum entropy methods: A comparative study. Landslides 2013, 10, 175-189. [CrossRef]

58. Chen, W.; Sun, Z.; Han, J. Landslide susceptibility modeling using integrated ensemble weights of evidence with logistic regression and random forest models. Appl. Sci. 2019, 9, 171. [CrossRef]

59. Ozcift, A.; Gulten, A. Classifier ensemble construction with rotation forest to improve medical diagnosis performance of machine learning algorithms. Comput. Meth. Prog. Biomed. 2011, 104, 443-451. [CrossRef] [PubMed]

60. Abellán, J.; Moral, S. Building classification trees using the total uncertainty criterion. Int. J. Intell. Syst. 2003, 18, 1215-1225. [CrossRef]

61. Breiman, L. Bagging predictors. Mach. Learn. 1996, 24, 123-140. [CrossRef]

62. Amthauer, H.A.; Tsatsoulis, C. Classifying genes to the correct gene ontology slim term in saccharomyces cerevisiae using neighbouring genes with classification learning. BMC Genom. 2010, 11, 340. [CrossRef] [PubMed]

63. Available online: Http://www.Linyou.Gov.Cn/ (accessed on 18 December 2018).

64. Demir, G. Landslide susceptibility mapping by using statistical analysis in the north anatolian fault zone (nafz) on the northern part of suşehri town, turkey. Nat. Hazards 2018, 92, 133-154. [CrossRef]

65. ESRI. Arcgis Desktop: Release 10.2 Redlands, CA: Environmental Systems Research Institute. Available online: Https:/ / www.esri.com/zh-cn/home. (accessed on 15 December 2018).

66. Hungr, O.; Leroueil, S.; Picarelli, L. The varnes classification of landslide types, an update. Landslides 2014, 11, 167-194. [CrossRef]

67. Hong, H.; Ilia, I.; Tsangaratos, P.; Chen, W.; Xu, C. A hybrid fuzzy weight of evidence method in landslide susceptibility analysis on the wuyuan area, china. Geomorphology 2017, 290, 1-16. [CrossRef]

68. Kumar, D.; Thakur, M.; Dubey, C.S.; Shukla, D.P. Landslide susceptibility mapping \& prediction using support vector machine for mandakini river basin, garhwal himalaya, india. Geomorphology 2017, 295, 115-125.

69. Samia, J.; Temme, A.; Bregt, A.; Wallinga, J.; Guzzetti, F.; Ardizzone, F.; Rossi, M. Characterization and quantification of path dependency in landslide susceptibility. Geomorphology 2017, 292, 16-24. [CrossRef]

70. Wu, C.-H. Landslide susceptibility mapping by using landslide ratio-based logistic regression: A case study in the southern taiwan. J. Mt. Sci. 2015, 12, 721-736. [CrossRef]

71. Sterlacchini, S.; Ballabio, C.; Blahut, J.; Masetti, M.; Sorichetta, A. Spatial agreement of predicted patterns in landslide susceptibility maps. Geomorphology 2011, 125, 51-61. [CrossRef]

72. Samia, J.; Temme, A.; Bregt, A.K.; Wallinga, J.; Stuiver, J.; Guzzetti, F.; Ardizzone, F.; Rossi, M. Implementing landslide path dependency in landslide susceptibility modelling. Landslides 2018, 15, 2129-2144. [CrossRef]

73. Available online: Https:/ / www.Nasa.Gov/ (accessed on 18 December 2018).

74. Pradhan, B.; Sameen, M.I. Effects of the spatial resolution of digital elevation models and their products on landslide susceptibility mapping. In Laser Scanning Applications in Landslide Assessment; Pradhan, B., Ed.; Springer International Publishing: Berlin, Germany, 2017; pp. 133-150.

75. Chen, W.; Li, W.; Chai, H.; Hou, E.; Li, X.; Ding, X. Gis-based landslide susceptibility mapping using analytical hierarchy process (ahp) and certainty factor (cf) models for the baozhong region of baoji city, china. Environ. Earth Sci. 2015, 75, 63. [CrossRef]

76. Yu, B.; Chen, F.; Muhammad, S. Analysis of satellite-derived landslide at central nepal from 2011 to 2016. Environ. Earth Sci. 2018, 77, 331. [CrossRef]

77. Lin, C.-Y.; Lo, H.-M.; Chou, W.-C.; Lin, W.-T. Vegetation recovery assessment at the jou-jou mountain landslide area caused by the 921 earthquake in central taiwan. Ecol. Model. 2004, 176, 75-81. [CrossRef]

78. Aksoy, B.; Ercanoglu, M. Landslide identification and classification by object-based image analysis and fuzzy logic: An example from the azdavay region (kastamonu, turkey). Comput. Geosci. 2012, 38, 87-98. [CrossRef] 
79. Jiang, J.-W.; Xiang, W.; Rohn, J.; Zeng, W.; Schleier, M. Research on water-rock (soil) interaction by dynamic tracing method for huangtupo landslide, three gorges reservoir, pr china. Environ. Earth Sci. 2015, 74, 557-571. [CrossRef]

80. Alvioli, M.; Guzzetti, F.; Rossi, M. Scaling properties of rainfall induced landslides predicted by a physically based model. Geomorphology 2014, 213, 38-47. [CrossRef]

81. Mugagga, F.; Kakembo, V.; Buyinza, M. Land use changes on the slopes of mount elgon and the implications for the occurrence of landslides. CATENA 2012, 90, 39-46. [CrossRef]

82. Fell, R.; Corominas, J.; Bonnard, C.; Cascini, L.; Leroi, E.; Savage, W.Z. Guidelines for landslide susceptibility, hazard and risk zoning for land use planning. Eng. Geol. 2008, 102, 85-98. [CrossRef]

83. Chen, H.; Lin, G.-W.; Lu, M.-H.; Shih, T.-Y.; Horng, M.-J.; Wu, S.-J.; Chuang, B. Effects of topography, lithology, rainfall and earthquake on landslide and sediment discharge in mountain catchments of southeastern taiwan. Geomorphology 2011, 133, 132-142. [CrossRef]

84. Segoni, S.; Rossi, G.; Rosi, A.; Catani, F. Landslides triggered by rainfall: A semi-automated procedure to define consistent intensity-duration thresholds. Comput. Geosci. 2014, 63, 123-131. [CrossRef]

85. Peruccacci, S.; Brunetti, M.T.; Gariano, S.L.; Melillo, M.; Rossi, M.; Guzzetti, F. Rainfall thresholds for possible landslide occurrence in italy. Geomorphology 2017, 290, 39-57. [CrossRef]

86. Bayer, B.; Simoni, A.; Mulas, M.; Corsini, A.; Schmidt, D. Deformation responses of slow moving landslides to seasonal rainfall in the northern apennines, measured by insar. Geomorphology 2018, 308, 293-306. [CrossRef]

87. Available online: Http:/ / www.Sxmb.Gov.Cn/ (accessed on 18 December 2018).

88. Abellán, J.; Masegosa, A.R. Combining Decision Trees Based on Imprecise Probabilities and Uncertainty Measures; Springer: Berlin/Heidelberg, Germany, 2007; pp. 512-523.

89. Shafer, G.A. Mathematical Theory of Evidence; Princeton University Press: Princeton, NJ, USA, 1976.

90. Dempster, A.P. Upper and lower probabilities induced by a multivalued mapping. In Classic Works of the Dempster-Shafer Theory of Belief Functions; Yager, R.R., Liu, L., Eds.; Springer: Berlin/Heidelberg, Germany, 2008; pp. 57-72.

91. Abellan, J.; Moral, S. A non-specificity measure for convex sets of probability distributions. Int. J. Uncertain. Fuzziness Knowl. Based Syst. 2000, 8, 357-367. [CrossRef]

92. Abellan, J.; Moral, S. Completing a total uncertainty measure in the dempster-shafer theory. Int. J. Gen. Syst. 1999, 28, 299-314. [CrossRef]

93. Walley, P. Inferences from multinomial data: Learning about a bag of marbles. J. R. Stat. Soc. Ser. B (Methodol.) 1996, 58, 3-57. [CrossRef]

94. Mantas, C.J.; Abellán, J. Hybrid Artificial Intelligence Systems. In Credal Decision Trees to Classify Noisy Data Sets; Polycarpou, M., de Carvalho, A.C.P.L.F., Pan, J.-S., Woźniak, M., Quintian, H., Corchado, E., Eds.; Springer International Publishing: Berlin, Germany, 2014; pp. 689-696.

95. Pham, B.T.; Nguyen, V.-T.; Ngo, V.-L.; Trinh, P.T.; Ngo, H.T.T.; Tien Bui, D. A novel hybrid model of rotation forest based functional trees for landslide susceptibility mapping: A case study at kon tum province, Vietnam. In Advances and Applications in Geospatial Technology and Earth Resources; Tien Bui, D., Ngoc Do, A., Bui, H.-B., Hoang, N.-D., Eds.; Springer International Publishing: Berlin, Germany, 2018; pp. 186-201.

96. Hong, H.; Liu, J.; Bui, D.T.; Pradhan, B.; Acharya, T.D.; Pham, B.T.; Zhu, A.X.; Chen, W.; Ahmad, B.B. Landslide susceptibility mapping using $\mathrm{j} 48$ decision tree with adaboost, bagging and rotation forest ensembles in the guangchang area (china). CATENA 2018, 163, 399-413. [CrossRef]

97. Pham, B.T.; Shirzadi, A.; Tien Bui, D.; Prakash, I.; Dholakia, M.B. A hybrid machine learning ensemble approach based on a radial basis function neural network and rotation forest for landslide susceptibility modeling: A case study in the himalayan area, india. Int. J. Sediment Res. 2018, 33, 157-170. [CrossRef]

98. Rodríguez, J.J.; Kuncheva, L.I.; Alonso, C.J. Rotation forest: A new classifier ensemble method. IEEE Trans. Pattern Anal. Mach. Intell. 2006, 28, 1619-1630. [CrossRef]

99. Kotsianti, S.B.; Kanellopoulos, D. Combining bagging, boosting and dagging for classification problems. In Knowledge-Based Intelligent Information and Engineering Systems; Apolloni, B., Howlett, R.J., Jain, L., Eds.; Springer: Berlin/Heidelberg, Germany, 2007; pp. 493-500.

100. Skurichina, M.; Duin, R.P.W. The role of combining rules in bagging and boosting. In Advances in Pattern Recognition; Ferri, F.J., Iñesta, J.M., Amin, A., Pudil, P., Eds.; Springer: Berlin/Heidelberg, Germany, 2000; pp. 631-640. 
101. Webb, G.I. Multiboosting: A technique for combining boosting and wagging. Mach. Learn. 2000, 40, $159-196$. [CrossRef]

102. Kotsiantis, S. Combining bagging, boosting, rotation forest and random subspace methods. Artif. Intell. Rev. 2011, 35, 223-240. [CrossRef]

103. Bauer, E.; Kohavi, R. An empirical comparison of voting classification algorithms: Bagging, boosting, and variants. Mach. Learn. 1999, 36, 105-139. [CrossRef]

104. Jaafari, A.; Najafi, A.; Pourghasemi, H.; Rezaeian, J.; Sattarian, A. Gis-based frequency ratio and index of entropy models for landslide susceptibility assessment in the caspian forest, northern iran. Int. J. Environ. Sci. Technol. 2014, 11, 909-926. [CrossRef]

105. Witten, I.H.; Frank, E.; Mark, A.H. Data Mining: Practical Machine Learning Tools and Techniques, 3rd ed.; Morgan kaufmann: Burlington, MA, USA, 2011.

106. Ching, J.; Phoon, K.-K. Quantile value method versus design value method for calibration of reliability-based geotechnical codes. Struct. Saf. 2013, 44, 47-58. [CrossRef]

107. Zhao, W.; Lian, H. Quantile index coefficient model with variable selection. J. Multivar. Anal. 2017, 154, 40-58. [CrossRef]

108. Lee, C.-F.; Huang, W.-K.; Chang, Y.-L.; Chi, S.-Y.; Liao, W.-C. Regional landslide susceptibility assessment using multi-stage remote sensing data along the coastal range highway in northeastern taiwan. Geomorphology 2018, 300, 113-127. [CrossRef]

109. Chen, W.; Li, H.; Hou, E.; Wang, S.; Wang, G.; Panahi, M.; Li, T.; Peng, T.; Guo, C.; Niu, C.; et al. Gis-based groundwater potential analysis using novel ensemble weights-of-evidence with logistic regression and functional tree models. Sci. Total Environ. 2018, 634, 853-867. [CrossRef] [PubMed]

110. Chen, W.; Zhang, S.; Li, R.; Shahabi, H. Performance evaluation of the gis-based data mining techniques of best-first decision tree, random forest, and naïve bayes tree for landslide susceptibility modeling. Sci. Total Environ. 2018, 644, 1006-1018. [CrossRef]

111. Chen, W.; Yan, X.; Zhao, Z.; Hong, H.; Bui, D.T.; Pradhan, B. Spatial prediction of landslide susceptibility using data mining-based kernel logistic regression, naive bayes and rbfnetwork models for the long county area (china). Bull. Eng. Geol. Environ. 2018, 1-20. [CrossRef]

112. Pham, B.T.; Tien Bui, D.; Pourghasemi, H.R.; Indra, P.; Dholakia, M. Landslide susceptibility assesssment in the uttarakhand area (india) using gis: A comparison study of prediction capability of naïve bayes, multilayer perceptron neural networks, and functional trees methods. Theor. Appl. Climatol. 2017, 128, 255-273. [CrossRef]

113. Gonzalez-Ollauri, A.; Mickovski, S.B. Plant-soil reinforcement response under different soil hydrological regimes. Geoderma 2017, 285, 141-150. [CrossRef]

114. Ordak, M.; Wesolowski, M.; Radecka, I.; Muszynska, E.; Bujalska-Zazdrozny, M. Seasonal variations of mercury levels in selected medicinal plants originating from poland. Biol. Trace Elem. Res. 2016, 173, 514-524. [CrossRef] [PubMed]

115. Zhang, C.-B.; Chen, L.-H.; Jiang, J. Why fine tree roots are stronger than thicker roots: The role of cellulose and lignin in relation to slope stability. Geomorphology 2014, 206, 196-202. [CrossRef]

116. Persichillo, M.G.; Bordoni, M.; Meisina, C. The role of land use changes in the distribution of shallow landslides. Sci. Total Environ. 2017, 574, 924-937. [CrossRef] [PubMed]

117. Bozo, L.; Cela, K. Problems with landslide stabilization of dukat in the road vlora-Saranda. Procedia Eng. 2016, 143, 1435-1442. [CrossRef]

118. Xu, C.; Dai, F.; Xu, X.; Lee, Y.H. Gis-based support vector machine modeling of earthquake-triggered landslide susceptibility in the jianjiang river watershed, china. Geomorphology 2012, 145-146, 70-80. [CrossRef]

119. Hong, H.; Pourghasemi, H.R.; Pourtaghi, Z.S. Landslide susceptibility assessment in lianhua county (china): A comparison between a random forest data mining technique and bivariate and multivariate statistical models. Geomorphology 2016, 259, 105-118. [CrossRef]

120. Chen, W.; Pourghasemi, H.R.; Kornejady, A.; Zhang, N. Landslide spatial modeling: Introducing new ensembles of ann, maxent, and svm machine learning techniques. Geoderma 2017, 305, 314-327. [CrossRef]

121. Truong, X.; Mitamura, M.; Kono, Y.; Raghavan, V.; Yonezawa, G.; Truong, X.; Do, T.; Tien Bui, D.; Lee, S. Enhancing prediction performance of landslide susceptibility model using hybrid machine learning approach of bagging ensemble and logistic model tree. Appl. Sci. 2018, 8, 146. [CrossRef] 
122. Barrios, E.; Gajardo, P.; Vasilieva, O. Sustainable thresholds for cooperative epidemiological models. Math. Biosci. 2018, 302, 9-18. [CrossRef]

123. Kim, M.-H.; Baik, H.; Lee, S. Response threshold model based uav search planning and task allocation. J. Intell. Robot. Syst. 2014, 75, 625-640. [CrossRef] 